\title{
A Framework for Monitoring Ecosystems-Based Adaptation to Climate Change: Experience from The Gambia
}

\author{
Peter Gilruth $^{1, *}$, Lalisa A. Duguma ${ }^{1} \oplus$, Peter A. Minang ${ }^{1}$, Alagie Bah ${ }^{2}$, Malanding S. Jaiteh ${ }^{3}$, Solomon Mwangi ${ }^{1}$ \\ and Muhammad Ahmad ${ }^{1}$ \\ 1 World Agroforestry (ICRAF), Nairobi P.O. Box 30677-00100, Kenya; L.A.Duguma@cgiar.org (L.A.D.); \\ p.minang@cgiar.org (P.A.M.); K.S.mwangi@cgiar.org (S.M.); m.ahmad@cgiar.org (M.A.) \\ 2 World Agroforestry (ICRAF), C/O EbA Project, 2nd Floor, Sky Blue Plaza, Bijilo Annex Layout, \\ West Coast Region, The Gambia; b.alagie@cgiar.org \\ 3 EbA Project, 2nd Floor, Sky Blue Plaza, Bijilo Annex Layout, West Coast Region, The Gambia; \\ msjaiteh@ebagambia.com \\ * Correspondence: p.gilruth@cgiar.org
}

check for updates

Citation: Gilruth, P.; Duguma, L.A.; Minang, P.A.; Bah, A.; Jaiteh, M.S.;

Mwangi, S.; Ahmad, M. A

Framework for Monitoring

Ecosystems-Based Adaptation to

Climate Change: Experience from The Gambia. Sustainability 2021, 13, 10959. https://doi.org/10.3390/ su131910959

Academic Editors: Andrei P. Kirilenko and Stephen M. Wheeler

Received: 29 July 2021

Accepted: 30 September 2021

Published: 2 October 2021

Publisher's Note: MDPI stays neutral with regard to jurisdictional claims in published maps and institutional affiliations.

Copyright: (c) 2021 by the authors. Licensee MDPI, Basel, Switzerland. This article is an open access article distributed under the terms and conditions of the Creative Commons Attribution (CC BY) license (https:/ / creativecommons.org/licenses/by/ $4.0 /)$.

\begin{abstract}
Implementing ecosystems-based adaptation (EbA) to climate change is challenged by the need to monitor biophysical, socio-cultural, and economic impacts which are usually contextspecific. Therefore, robust frameworks are required that integrate impacts to better understand EbA effectiveness. Monitoring frameworks that are universally applicable to EbA are desirable, however their universal application is problematic as they should reflect a community-driven design that accommodates both donor reporting functions and the generation of local-level data and information to support management actions and community initiatives. Initial products from this research include a generic, five-step process for developing and testing adaptation indicators, a robust framework consisting of (i) the indicators, data and information used to design the framework, (ii) the operational EbA platform that houses and computes the adaptation indicators, and (iii) the participating institutions, and initial, community-level applications to guide water management, replenishment of the vegetation cover, and business development. Immediate benefits to rural communities include the re-orientation of performance indicators mapped to their needs as opposed to donor reporting alone. The framework contributes to the set of tools currently in use for EbA monitoring by offering an umbrella within which existing tools can be applied. Near-term future research will focus on improving the utility of the framework and its platform beyond reporting on key performance indicators (KPIs) by adapting the EbA platform to support changing management needs. Future research will be needed to understand the extent to which the environmental changes in The Gambia compared to changes across the Sahel and Sudano-Sahel regions of West Africa and whether the lessons learned from The Gambia could be extrapolated to the subregion.
\end{abstract}

Keywords: resilience; vulnerability; participatory monitoring; context-driven; indicator; performance

\section{Introduction}

Earth's ecosystems are the foundation for human development, so their health is essential for the social and economic security of its population. As demand for ecosystem services escalates with the global population projected to reach 9.7 billion in 2050 [1], so will pressure on food production, particularly in the face of climate change [2].

As the Intergovernmental Panel on Climate Change (IPCC) has reported, the global climate system has warmed, and the changes observed since the 1950s are unprecedented within periods spanning from decades to millennia. Increasing concentrations of greenhouse gases (GHGs) from anthropogenic sources have triggered this atmospheric and oceanic warming. As a consequence, snow and ice packs have diminished, while the sea level has risen. Continued emissions of GHGs will cause further warming and changes in components of the climate system [3]. 
Nevertheless, IPCC predictions state that changes in the global water cycle in response to warming will be uneven. Contrasts in precipitation between wet and dry regions and between wet and dry seasons will increase. The IPCC notes that there may be regional exceptions. For example, extreme precipitation events over wet tropical regions will very likely become more intense and more frequent by the end of this century, as global mean surface temperature increases [3].

With respect to climate change in Africa, although there are still large gaps in the available data, there is growing evidence of changing temperature and rainfall patterns, consistent with anthropogenic climate change. Long-term temperature projections over West Africa to the end of the 21st century from global climate simulations range between 3 and $6{ }^{\circ} \mathrm{C}$ above the late 20th-century baseline depending on the emission scenario. With respect to rainfall trends, understanding of West African weather systems from the African Monsoon Multidisciplinary Analysis (AMMA; phase 1: 2002-2010, phase 2: 2010-2020) project has improved, as climate projections show a slight increase of total precipitation and a longer rainy season but with drier phases within [4].

Recent advances in models for studying climate change in West Africa inform regional authorities about drought risk, which is particularly important for food security in rainfed agriculture systems. Ajayi and Ilori [5] projected drought trends by applying Standardized Precipitation Evapotranspiration Index (SPEI) and Standardized Precipitation Index (SPI) under Representative Concentration Pathways (RCPs) 4.5 and 8.5 scenarios using Rossby Center Atmospheric Regional Model (RCA4) datasets. Projected drought events by the two indices show that areas north of $12^{\circ} \mathrm{N}$ of West Africa will be hot spots for mildly and moderately dry events, while the southern part of West Africa will witness pronounced severe and extreme dry events under both RCPs [5].

With regard to country-specific climate change modelling in West Africa, Duguma et al. [6] analyzed climate change and variability using historical data for The Gambia. They focused on bioclimatic variables of precipitation, potential evapotranspiration and minimum and maximum temperatures because of their usefulness for estimating impacts on vegetation distribution. For projecting future climatic changes, they used consensus approaches among general circulation models. All mid-21st century projections available from AFRICLIM [6] for Representative Concentration Pathways RCP4.5 (a medium emissions scenario) and RCP8.5 (a high-emissions scenario) were included. In checking for consensus among models, the likelihood scale recommended for the fifth assessment report of the IPCC [7] was adopted. Results were reported as likely in cases where at least $66 \%$ of models showed the same trend and as unlikely where at most $33 \%$ of models showed the same trend. They found that, as a result of the combined changes in temperatures and precipitation, that potential evapotranspiration (PET) is projected to increase, while the moisture index (MI) is projected to decrease [8].

In spite of these advances, James et al. [9] note that climate model development in Africa is lagging behind many regions of the world. If African climate models are to be improved, they should simulate regional climate dynamics and move from validation to process-based evaluation. Model evaluation may vary by region and requires local weather and climate data and expertise, as a "one size fits all" approach could overlook regional features crucial for adaptation planning such as that described in this article.

Ecosystem-based adaptation (EbA) to climate change encompasses a broad set of approaches based on strengthening ecosystem resilience. The Convention on Biodiversity (CBD) [10] defines EbA: as "the use of biodiversity and ecosystem services as part of an overall adaptation strategy to help people to adapt to the adverse effects of climate change".

Climate change adaptation (CCA) and $\mathrm{EbA} / \mathrm{CC}$ are not equivalent. Whereas CCA may cover a broad set of approaches to adjust to the eventual impacts of CC, (including urban renewal, economic incentives, environmental conservation, among others), an EbA approach focusses more directly on the total ecosystem within which a community thrives and thus includes socio-economic interactions. To be truly considered an EbA approach and to differentiate from other adaptation methods, the approach must embrace the following 
five principles: (i) reduce social and environmental vulnerabilities, (ii) generate societal benefits in the context of climate change adaptation, (iii) restore, maintain or improve ecosystem health, (iv) be supported by policies at multiple levels, and (v) support equitable governance and enhance community capacity to implement EbA initiatives [11]. These criteria form a structure for defining performance indicators to monitor adaptation.

$\mathrm{EbA}$ embraces the sustainable management of forests, grasslands, wetlands, and coastal zones to reduce the harmful impacts of climate hazards including shifting spatial and temporal variability of rainfall, changes in maximum and minimum temperatures, stronger storms, and increasingly variable climatic conditions [12]. Examples of EbA practices include agroforestry to increase resilience of crops to droughts or excessive rainfall, integrated water resource management to cope with prolonged drought and change in rainfall patterns, and sustainable forest management to stabilise slopes, prevent landslides, and regulate water flow [13].

$\mathrm{EbA}$ is nested within the broader concept of nature-based solutions and shares common elements with a variety of approaches to building the resilience of socio-ecological systems [14]. These approaches include community-based adaptation, ecosystem-based disaster risk reduction, climate-smart agriculture, and green infrastructure and often use participatory processes for community engagement. Not surprisingly, EbA is increasingly viewed as an effective means of addressing the linked challenges of climate change and poverty in developing countries, where many people are dependent on natural resources for their livelihoods [15].

Greater adoption of EbA faces several challenges including economic and financial constraints, social and cultural barriers, governance and institutional weaknesses, and difficulties in establishing the evidence base to show impact. This manuscript addresses the latter of these, as despite considerable investments going into monitoring EbA [16], generating the specific costs and benefits for monitoring EbA adaptation is not often clearly articulated.

Ever since the need to adapt to climate change was understood, the global CC community has sought a universal set of adaptation metrics. Christiansen et al. [17] noted that within the donor community (GCF, GEF, etc.), metrics are used to prioritize limited adaptation funding, including for comparing investments across regions, sectors, and contexts. Similarly, there was initially a need for monitoring for management accountability, hence the need for universal application.

In time, however, the need for tools that also guide project teams in results-based management grew, as adaptation metrics may be even more useful as learning and management tools than just for project evaluation and fund allocation.

No single set of metrics exists that will meet all needs. Context is crucial. Within the EbA community, managers must find a balance between conceptual approaches for better transparency and accountability and pragmatic tools for project monitoring and evaluation. Table 1 summarizes the advantages and disadvantages of universal metrics for adaptation.

Table 1. Advantages and disadvantages of universal metrics for adaptation (Adapted from Christiansen et al. [17]).

\begin{tabular}{ccc}
\hline Issues & Advantages & Disadvantages \\
\hline Political & $\begin{array}{c}\text { Reduced risk of squandering or } \\
\text { misappropriation of funds }\end{array}$ & $\begin{array}{c}\text { If recipient country has low capacity to collect and } \\
\text { report adaptation metrics, it may not have same } \\
\text { access to funds as a well-managed country }\end{array}$ \\
\hline Ethical & Transparency-allocation of funds based on merit. & $\begin{array}{c}\text { Allocation of funds will always have some level of } \\
\text { value judgement, so may not go to most in need. }\end{array}$ \\
\hline Economic & Ex-ante identification of promising projects & $\begin{array}{c}\text { Indicator measurement is uncertain, potentially } \\
\text { biasing allocation of funds to project wherein } \\
\text { benefits can easily be monetized. }\end{array}$ \\
\hline
\end{tabular}


Within the adaptation community, there is uncertainty as to what EbA encompasses. For example, in coastal zones, stabilization is an important EbA intervention if it reduces the vulnerability of coastal communities to sea level rise or river flooding. Appropriate metrics could include limited frequency or severity of flooding, lessened frequency of landslide, or reduced damage to properties due to water intrusion. However, if an $\mathrm{EbA}$ project addresses adaptation in farming systems, a different set of metrics must reflect the context where interventions are implemented. Since having a standardized indicator set for $\mathrm{EbA}$ is problematic, there is a need for teams implementing EbA to agree on appropriate metrics for the work while respecting the principles of transparency and accountability.

Finally, since EbA is achieved within an ecosystem, effective ecological practices must be combined with cultural and social aspects of adaptation.

\subsection{Problem Statement}

Current efforts to track ecosystems-based adaptation to climate change are challenged by the complexity of adaptation monitoring-not only because EbA touches multiple sectors which makes the selection of indicators difficult, but also because monitoring frameworks are often built to satisfy donor or national reporting needs, with universally applicable frameworks, and therefore may not fully capture the impacts at community levels. Hence, the research gap is that transparent processes and robust frameworks are needed to improve EbA monitoring. The research presented here contributes to the body of knowledge on EbA tools by developing a process and framework for monitoring $\mathrm{EbA}$ adaptation that satisfies both requirements. We use a case study from the Green Climate Fund (GCF) EbA project in The Gambia to present the lessons and emergent results acquired in the process of building a context-specific framework.

\subsection{An Overview of Efforts in Developing Monitoring Frameworks for Ecosystem-Based Interventions}

Various efforts to develop indicators of adaptation to climate change across different sectors have demonstrated the difficulty in developing robust monitoring frameworks. In the public health sector, Doubleday et al. [18] proposed a set of climate change indicators for state and local health departments to track adaptation efforts. However, they found that additional refinement based on local context was required to improve their uptake in policy and planning. Ebi et al. [19] learned that adaptation indicators must map to upstream drivers of climate-sensitive health outcomes. Indicators should monitor (1) vulnerability and exposure to climate-related hazards, (2) current impacts and projected risks, and (3) adaptation processes and health system resilience. To be robust, proposed indicators must capture uncertainties about the magnitude and pattern of climate change.

In the global environmental change sector in Europe, Klostermann et al. [20] also found that context is crucial for developing adaptation indicators, although they note that the provision of common framework elements would help European Union member states to create or improve their adaptation monitoring. To reduce the risk of environmental hazards in Carinthia, Austria, Zischg et al. [21] undertook an analysis of flood risks in all municipalities. The results were used to set priorities in planning flood protection and formed the basis for a monitoring system.

In the urban sector, Feldmeyer et al. [22] provided an indicator set to measure resilience to climate change and adaptation using a participatory approach to account for context-specific parameters. However, they found that a purely quantitative, indicatorbased approach was not sufficient and additional qualitative information was needed. For managing urban water projects, Larson et al. [23] noted the challenges of monitoring and evaluation (M\&E) required by funding agencies and recommended a combination of methods including logical frameworks and best/worst case scenarios depending on project stage and specific monitoring objectives. In the national energy sector, Pineda et al. [24] were successful in building a composite indicator that helped transition the Columbia energy sector from reactive to anticipatory scenarios. 
The European Commission (EC) [25] produced a handbook for developing frameworks and indicators for nature-based solutions (NBS) based on 17 EU-funded projects. The EC NBS framework serves as a reference for EU policies and programmes while orienting urban practitioners in preparing robust impact evaluation frameworks at different scales.

For biological conservation, Conroy et al. [26] noted that, although potential impacts of climate change are understood at global or regional scales, impacts at finer scales are not. Nevertheless, following the precautionary principle [27], conservation decisions cannot await "perfect information" and instead must proceed in the face of uncertainty. Moreover, conservation should precede in an adaptive management framework as new information becomes available.

From a more practical perspective, users of adaptation monitoring frameworks often need to integrate tools within a single platform. In some cases, the problem is simply technical and relates to the software or hardware used. Even more difficult is the integration of bio-physical and socio-economic data into decision support systems since scientists and the development practitioners whom they support often think and plan along themes and sectors but not necessarily across disciplines. Although additional training in crosssystems planning is useful, experience and wisdom gained through time will always be highly valued.

Finally, users prefer participatory, community-led, and gender-sensitive planning tools because these reflect the need to negotiate among interests in the real world [28]. It follows that user-defined tools should be given more attention than those originating from external sources.

\section{Methods}

The methodology for developing the framework consisted of a global review of existing EbA monitoring tools, an extensive baseline survey to identify data needs for $\mathrm{EbA}$ monitoring and gaps for the case study from The Gambia, selection of key performance indicators (KPIs) most relevant to local community needs, collection of field data, and $\mathrm{EbA}$ monitoring platform design and development.

The timeline for the framework development included: (i) GCF/Gambia project approved in 2016, (ii) work planning in 2017, (iii) review of literature (2017 and on-going), baseline survey in 2018-2019, field data collection in 2018-2019, indicator refinement in 2018-2019, platform development in 2018-2020, platform testing and validation in 2020-2021.

\subsection{Review of Existing Ecosystem-Based Adaptation (EbA) Monitoring Tools}

The initial step for this research was to assess existing EbA monitoring tools to guide indicator development and framework design. EbA monitoring tools are technologies designed for managers to explore options for the use of land resources based on their ecosystem characteristics and the socio-economic conditions of the population that depend on them. EbA technologies are mostly information technology (IT) based and support decision making in land evaluation, suitability analysis, land capability classification, and agro-ecological zoning. These options incorporate the needs of different sectors operating in a landscape while optimizing and sustaining resource use. However, the diversity of EbA tools to meet these wide needs challenges users who could benefit most from them.

$\mathrm{EbA}$ tools are similar to those used in sustainable land management (SLM) and are classified as biophysical, socio-economic, integrated tools, or databases and have overlapping characteristics.

Biophysical tools assist the user to analyse biophysical attributes (climate, soil, terrain, water, etc.) and their interactions for land evaluation. The output identifies EbA alternatives based on land suitability. For example, soils are classified based on suitability for a specific use, fertility constraints, and linkages to yield, productivity, physical and chemical properties. 
Socio-economic tools characterize social and economic settings required for EbA planning and implementation. They include approaches and methods of participatory data collection and decision-making and provide an understanding of the social capital that should be driving the implementation and monitoring processes.

Integrated tools include both biophysical characteristics and social and economic conditions and generally incorporate principles, approaches and methods of participatory planning, with the overall objective of reaching mutually beneficial outcomes for all stakeholders.

Databases can facilitate EbA planning by providing readily available data as input. These databases provide maps and data on soil and terrain characteristics, land degradation, land cover, land use, climatic data including future projections, crops and yields, food, agriculture, water resources, adaptability/suitability of identified plant species for a given environment, and socio-economic data and statistics on poverty, population, tenure and gender.

Information on these tools is not always easily accessible to those who need it. A useful starting point is the EbA Navigator tool produced by International Institute for Environment and Development (IIED), International Union for the Conservation of Nature (IUCN), UNEP-World Conservation Monitoring Centre (UNEP-WCMC) and Deutsche Gesellschaft für Internationale Zusammenarbeit (GIZ). The tool is available online at https: / / www.iied.org/help-pilot-navigator-tools-for-ecosystem-based-adaptation (accessed on 1 October 2021). This searchable database currently includes information on more than 240 tools and methods for planning, implementing and monitoring EbA or sustainable land management (SLM) activities.

Tools in the EbA Navigator fall into three categories, including overview documents, manuals and handbooks and tools specific to project needs. Overview documents provide context on ecosystem resilience or food security and are generally written at the global or regional levels but have limited use at a local project management scale. Manuals/short courses/handbooks for project management include project planning, theory of change, development of logframes, adaptive management, M\&E, etc. There are many such tools available, and some are required by specific donors for financial and technical reporting. Specific tools often are needed to access and/or process socio-economic or biophysical data, for example in data modelling.

Other efforts to develop tools are found within SLM practices and have many similarities with EbA. To assist SLM practitioners, the International Fund for Agricultural Development (IFAD) developed its Integrated Approach Programme (IFAD IAP) on Food Security (IAP-FS) in sub-Saharan Africa with funding from the Global Environment Facility (GEF). The IAP-FS targets agro-ecological systems in the drylands of Sub-Saharan Africa (SSA) where the need to enhance food security is directly linked to opportunities for generating local and global environmental benefits [29]. A summary of tools from the IAP-FS programme is given in Table 2.

Users often find it difficult adapting generic EbA tools to their specific needs due to their complexity. In a survey conducted by FAO [30], respondents mentioned the difficulty of using EbA tools in environments for which they were not designed or for which local data had to be generated through inference rather than observation. On the one hand, FAO [30] found that, despite technological advances in IT, remote sensing and GIS, tool development in EbA has not kept pace with new challenges in land and water resource management. The most common shortcomings were low spatial or temporal resolution, resulting in variable data quality and more general information than appropriate for the desired scale of operation. On the other hand, the survey found that such tools and knowledge will always be needed for supporting effective EbA that meets demand for land and water resources while enhancing governance at all scales.

The following section describes the methods used in developing EbA monitoring indicators and a framework from The Gambia, West Africa. 
Table 2. Sustainable land management (SLM) tools relevant for ecosystem-based adaptation (EbA).

\begin{tabular}{|c|c|c|c|c|}
\hline Tool & Type & Level & Theme & Comment and Access \\
\hline $\begin{array}{l}\text { Diversity Assessment } \\
\text { Tool for Agrobiodiversity } \\
\text { and Resilience (DATAR) }\end{array}$ & Survey & Farm & Agro-biodiversity & $\begin{array}{l}\text { As of 04/2021, DATAR data collection } \\
\text { has been limited to crop genetic } \\
\text { resources. https://www. } \\
\text { agrobiodiversityplatform.org/ datar } \\
\text { (accessed on } 1 \text { October 2021). }\end{array}$ \\
\hline $\begin{array}{c}\text { EX-Ante Carbon Balance } \\
\text { Tool (EX-ACT) }\end{array}$ & Survey & $\begin{array}{c}\text { Farm/ } \\
\text { Household }\end{array}$ & Carbon storage & $\begin{array}{l}\text { Designed for climate change projects } \\
\text { http://www.fao.org/tc/ exact/ex-act- } \\
\text { home/en/ (accessed on } 1 \text { October 2021). }\end{array}$ \\
\hline $\begin{array}{l}\text { Landscape Degradation } \\
\text { Surveillance Framework } \\
\text { (LDSF) }\end{array}$ & Inventory & Landscape & Land degradation & $\begin{array}{l}\text { Effectively combines satellite and } \\
\text { field data } \\
\text { http:/ / landscapeportal.org (accessed on } \\
\text { 1 October 2021). }\end{array}$ \\
\hline $\begin{array}{l}\text { Multidimensional } \\
\text { Poverty Assessment Tool } \\
\text { (MPAT) }\end{array}$ & Survey & Household & Poverty & $\begin{array}{l}\text { Thorough procedures for poverty } \\
\text { assessment https: } \\
\text { / / www.ifad.org/en/web/knowledge/ } \\
\text {-/ publication/the-multidimensional- } \\
\text { poverty-assessment-tool (accessed on } \\
\text { 1 October 2021). }\end{array}$ \\
\hline $\begin{array}{l}\text { Resilience, Adaptation } \\
\text { Pathways and } \\
\text { Transformation } \\
\text { Assessment (RAPTA) }\end{array}$ & Assessment process & Multiscalar & Resilience & $\begin{array}{c}\text { Strong participatory component } \\
\text { https:// /research.csiro.au/eap/rapta / } \\
\text { (accessed on } 1 \text { October 2021). }\end{array}$ \\
\hline RESILIENCE ATLAS & $\begin{array}{l}\text { Geographic } \\
\text { Information System } \\
\text { (GIS) / Map }\end{array}$ & Multiscalar & Land degradation & $\begin{array}{l}\text { Maps generated for planning and } \\
\text { communication } \\
\text { https:/ / www.resilienceatlas.org/ } \\
\text { (accessed on 1 October 2021). }\end{array}$ \\
\hline $\begin{array}{c}\text { Self-evaluation and } \\
\text { Holistic Assessment } \\
\text { of climate } \\
\text { Resilience of farmers and } \\
\text { Pastoralists (SHARP) }\end{array}$ & Survey & $\begin{array}{c}\text { Farm/ } \\
\text { Household }\end{array}$ & Climate resilience & $\begin{array}{l}\text { Farmer level survey improves their } \\
\text { engagement in resilience planning } \\
\text { http:/ / www.fao.org/in-action/sharp/ } \\
\text { resources/publications/en/ (accessed on } \\
\text { 1 October 2021). }\end{array}$ \\
\hline VITAL SIGNS & Inventory & Multiscalar & Risk assessment & $\begin{array}{l}\text { Useful for capacity building, awareness } \\
\text { raising on resilience https://www. } \\
\text { conservation.org/projects/vital-signs } \\
\text { (accessed on } 1 \text { October 2021). }\end{array}$ \\
\hline $\begin{array}{l}\text { Land Degradation } \\
\text { Assessment in } \\
\text { Drylands Mapping } \\
\text { Tool (WOCAT-LADA) }\end{array}$ & Survey/GIS/Map & Multiscalar & Land degradation & $\begin{array}{c}\text { Primary focus on dryland degradation } \\
\text { http:// /www.fao.org/land-water/land/ } \\
\text { land-assessment/assessment-and- } \\
\text { monitoring-impacts/en (accessed on } \\
\text { 1 October 2021). }\end{array}$ \\
\hline
\end{tabular}

\subsection{Case Study: Monitoring Ecosystem Based Adaptation Outcomes in The Gambia}

Poverty and environmental degradation threaten rural livelihoods in The Gambia. Climate change exacerbates these threats as droughts and floods are increasingly severe, resulting in reduced agricultural production and unsustainable extraction of resources from forest ecosystems by rural households. At present, the Government of The Gambia (GoTG) has insufficient financial resources and technical capacity to build the climate resilience of rural Gambians [31] as outlined in its National Adaptation Program of Action (NAPA).

Sanneh et al. [32] developed a survey-based method for prioritizing climate change adaptation based on the NAPA in The Gambia. Their results indicated that the five most important adaptation categories in order of priority were health, forestry, water, food security, and energy. Furthermore, adaptation approaches included health education, public sensitization, water supply infrastructure development, microfinance, and infrastructure and technology enhancement [32]. The case study chosen takes a step toward implementing these approaches.

The Green Climate Fund (GCF) has been a champion of promoting climate change adaptation with over 60 projects worldwide [16]. As a priority, GCF operates in developing 
countries which typically are most at risk to climate change as possibilities to adapt may be lacking.

With the GoTG's Ministry of Environment, Climate Change and Natural Resources (MECCNR) as the Executing Agency, and the UN Environment Programme (UNEP) as the Implementing Agency, The Gambia was chosen as a focus country for GCF support because it is on the frontline of the struggle to reduce climate change impacts and because its ecosystem resources are fundamental for survival of its mostly rural population. The International Centre for Research in Agroforestry (ICRAF) was selected as the technical partner supporting project implementation.

The GCF solution is the large-scale implementation of the EbA approach including community forests (CFs), community protected areas (CPAs) and agroforestry on farms in participation with local communities [31] through the project 'Large-scale Ecosystembased Adaptation in The Gambia: Developing a climate-resilient, natural resource-based economy' (hereafter referred to as 'The GCF project'). Project details are available at https: / / www.greenclimate.fund/project/fp011 (accessed on 1 October 2021).

The project's investments in EbA: (i) increase the generation of ecosystem goods and services through establishment of a climate-resilient natural resource base; and (ii) identify and promote climate-resilient livelihood options for rural communities through establishment and protection of natural resource-based businesses, for example sustainable production and marketing of timber, firewood, honey and fruit [31].

EbA monitoring in The Gambia has relevance at different scales. At local and national levels, EbA monitoring feeds into land use planning and decision making based on data collected at the appropriate scale (1:50,000 or larger). Examples of local level applications include location of water collection points for farming and tree nursery development, learning which multi-purpose community group interventions have greatest potential for sustainability after project end, or confirming which indigenous tree species have the greatest survival rate with the objective of repairing ecosystem biodiversity and improving community resilience to climate change.

At regional and global levels, EbA monitoring contributes to better science which encourages collaboration through establishing common baselines, knowing trends, assessing risks and further informing policy at regional or national levels. Land managers in West Africa need to strengthen monitoring systems to understand regional climate and environmental dynamics since Sahelian populations are at high risk of increased precipitation variability, droughts and floods [33]. For example, knowing regional trends allows decision makers (Senegal and The Gambia) to benefit from synergistic planning, improve the science of species biodiversity, remove trade barriers to permit local producers better access to markets, and improve ecosystem resilience at regional scale.

This longer-term research objective, although not addressed in the current manuscript, is intended to meet higher level adaptation monitoring efforts that contribute to the global body of knowledge while emphasizing critical considerations of local contexts.

The true value of EbA monitoring is felt most when integrating both local and regional levels by aligning top-down and bottom-up planning and implementation.

\subsection{Predefined Project Key Performance Indicators (KPIs)}

Methods to develop the framework and populate its EbA monitoring platform with data and statistics are grouped according to (1) processes to select, develop, test, validate, and implement KPIs and internal project management indicators; and (2) processes to design, develop, test and deliver the EbA monitoring platform and its geo-data portal. The two sets of processes are integral to each other and were designed accordingly.

KPI selection and development were characterized by participatory processes throughout project implementation. An initial set was defined by the GCF, UNEP, and GoTG and subsequently approved by the GCF [31]. However, the process to select and validate indicators needed further buy-in and adjustment from national project stakeholders, particularly from the team responsible for project management and reporting. 
An inception workshop was held on 17-18 May 2018 (Figure 1) to review the predefined KPIs and make the monitoring process more effective and efficient. For the predefined KPIs, relevant data available and the current locations of the identified data were specified (Table 3).

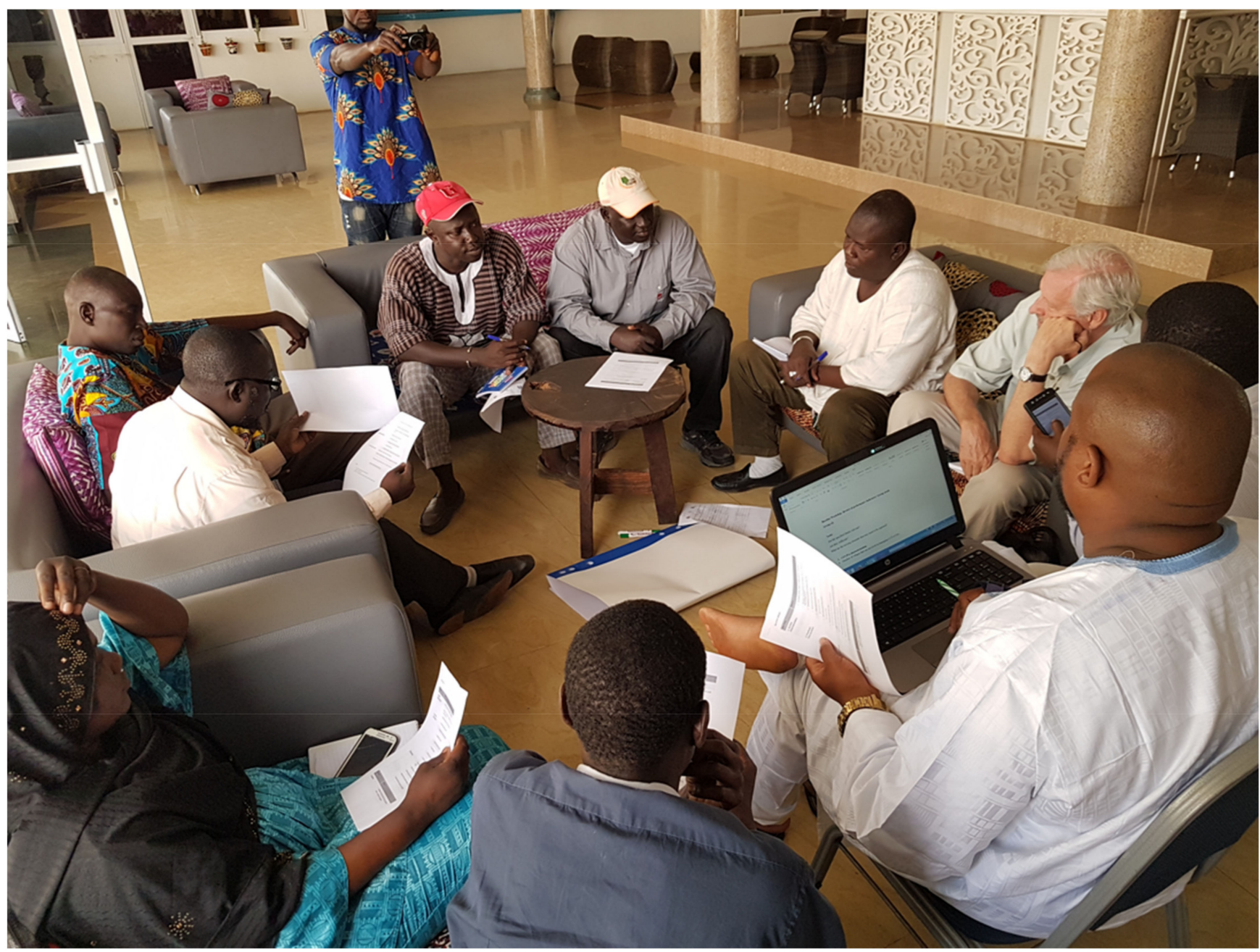

Figure 1. Indicator development and confirmation working groups (ICRAF 17 May 2018).

The main gaps identified by the working groups were that the KPIs were not specific enough to reflect project outcomes while meeting management needs. Hence, the working groups identified sub-indicators for each KPI. The specificity of the sub-indicators made the monitoring practical and easier for local practitioners to apply. The project team used a bottom-up process to validate indicators by tagging them to EbA activities preferred by local communities such as beekeeping, fruit production, sale of woodfuels, etc. After the inception workshop, the list of sub-indicators was further refined to include number of trees planted, mortality rate, and number of knowledge products. 
Table 3. Examples of user derived indicator sets for monitoring EbA.

\begin{tabular}{|c|c|c|c|c|}
\hline KPIs & Units & $\begin{array}{c}\text { Existing Data } \\
\text { Relevant to the KPIs }\end{array}$ & $\begin{array}{l}\text { Location of Data } \\
\text { Repository }\end{array}$ & $\begin{array}{c}\text { Feasible Scale of } \\
\text { Assessment }\end{array}$ \\
\hline Benefit generation & $\begin{array}{l}\text { Income for household } \\
\text { (Dalassi) }\end{array}$ & Household survey & Bureau of Statistics & Household level \\
\hline Restoration & $\begin{array}{l}\text { Areas of forest restored } \\
\text { through tree planting }\end{array}$ & $\begin{array}{l}\text { Monitoring and } \\
\text { evaluation reports }\end{array}$ & Department of Forestry & $\begin{array}{l}\text { National and } \\
\text { regional levels }\end{array}$ \\
\hline Degradation & No. of trees cut/ha & $\begin{array}{c}\text { National Forest } \\
\text { assessment survey. }\end{array}$ & Department of Forestry & National level \\
\hline $\begin{array}{c}\text { Training and } \\
\text { capacity development }\end{array}$ & $\begin{array}{l}\text { No. of technical } \\
\text { staff trained }\end{array}$ & Sector plans & All departments & National level \\
\hline $\begin{array}{l}\text { Investment in natural } \\
\text { resource (NR)-based } \\
\text { businesses }\end{array}$ & $\begin{array}{l}\text { Investment in natural } \\
\text { resource-based } \\
\text { (Dalassi) }\end{array}$ & $\begin{array}{l}\text { Market Analysis and } \\
\text { Development report }\end{array}$ & Department of Forestry & National level \\
\hline $\begin{array}{c}\text { Contribution to } \\
\text { National Forest fund }\end{array}$ & $\begin{array}{l}\text { Tax paid from NR- } \\
\text { businesses (Dalassi) }\end{array}$ & $\begin{array}{l}\text { Regional records of } \\
\text { licensing issuance }\end{array}$ & Department of Forestry & $\begin{array}{c}\text { Subnational (regional) } \\
\text { level }\end{array}$ \\
\hline $\begin{array}{l}\text { Mainstreaming EbA } \\
\text { in policies }\end{array}$ & $\begin{array}{c}\text { No. of policies and } \\
\text { strategies integrating } \\
\text { EbA }\end{array}$ & $\begin{array}{c}\text { EbA } \\
\text { Stakeholders }\end{array}$ & $\begin{array}{c}\text { Departments of } \\
\text { Community } \\
\text { Development, Forestry } \\
\text { and parks and wildlife }\end{array}$ & $\begin{array}{c}\text { National and } \\
\text { subnational (regional) } \\
\text { level }\end{array}$ \\
\hline
\end{tabular}

\subsection{The Need for a Robust Platform for EbA Monitoring}

Table 4 summarizes the data and information needs for the GCF Gambia project stakeholders.

Table 4. Data and information needs for monitoring EbA in The Gambia.

\begin{tabular}{|c|c|c|c|c|c|}
\hline $\begin{array}{l}\text { Who Needs } \\
\text { Monitoring Info? }\end{array}$ & $\begin{array}{c}\text { What Monitoring } \\
\text { Information Do They Need? }\end{array}$ & Why Do They Need It? & $\begin{array}{l}\text { When Do They } \\
\text { Need It? }\end{array}$ & $\begin{array}{l}\text { In What Form Do } \\
\text { They Need It? }\end{array}$ & $\begin{array}{l}\text { Where Do They } \\
\text { Need It? }\end{array}$ \\
\hline $\begin{array}{l}\text { Village business } \\
\text { groups }\end{array}$ & $\begin{array}{c}\text { Gender disaggregated } \\
\text { Information on new markets } \\
\text { for EbA products; } \\
\text { nutritional benefits }\end{array}$ & $\begin{array}{c}\text { To increase opportunities } \\
\text { for economic } \\
\text { development; improve } \\
\text { family and } \\
\text { community health }\end{array}$ & $\begin{array}{l}\text { To feed into } \\
\text { periodic village } \\
\text { meetings }\end{array}$ & $\begin{array}{l}\text { Price data, profit } \\
\text { margins, etc. } \\
\text { packaged within } \\
\text { awareness raising } \\
\text { campaigns }\end{array}$ & $\begin{array}{l}\text { Within their } \\
\text { villages }\end{array}$ \\
\hline $\begin{array}{l}\text { Community } \\
\text { leaders }\end{array}$ & $\begin{array}{l}\text { New EbA policy directed } \\
\text { toward their location; } \\
\text { Information on new markets } \\
\text { for EbA products; } \\
\text { nutritional benefits }\end{array}$ & $\begin{array}{l}\text { To provide direction to } \\
\text { local communities on } \\
\text { business and social } \\
\text { opportunities }\end{array}$ & $\begin{array}{l}\text { In advance of } \\
\text { periodic village } \\
\text { meetings to plan }\end{array}$ & $\begin{array}{l}\text { Materials for } \\
\text { communicating } \\
\text { information to } \\
\text { village groups }\end{array}$ & $\begin{array}{l}\text { Within their } \\
\text { villages }\end{array}$ \\
\hline EbA project staff & $\begin{array}{l}\text { Data on social and ecosystem } \\
\text { trends compared to baseline; } \\
\text { cost-benefit of EbA options; } \\
\text { degree of community uptake }\end{array}$ & $\begin{array}{c}\text { Identify lessons learned; } \\
\text { identify new EbA } \\
\text { opportunities, to support } \\
\text { project management on } \\
\text { daily basis }\end{array}$ & $\begin{array}{l}\text { Bi-monthly or } \\
\text { more frequently, } \\
\text { depending on } \\
\text { season. }\end{array}$ & $\begin{array}{l}\text { Raw data initially but } \\
\text { aggregated to } \\
\text { information for } \\
\text { sharing with national } \\
\text { policy makers as well } \\
\text { as local village } \\
\text { leaders. }\end{array}$ & $\begin{array}{l}\text { Banjul and } \\
\text { regional offices. }\end{array}$ \\
\hline $\begin{array}{l}\text { National Policy } \\
\text { makers }\end{array}$ & $\begin{array}{l}\text { Aggregated data on social } \\
\text { and environmental trends } \\
\text { compared to baseline }\end{array}$ & $\begin{array}{l}\text { Evolve new EbA policies } \\
\text { for implementation; gain } \\
\text { political support for EbA. }\end{array}$ & Twice yearly & $\begin{array}{l}\text { Aggregated } \\
\text { information products } \\
\text { to feed into policy } \\
\text { design }\end{array}$ & Banjul \\
\hline Donors/partners & $\begin{array}{l}\text { Key performance indicators } \\
\text { (KPIs), return on investment, } \\
\text { success stories, problems } \\
\text { encountered, other impacts }\end{array}$ & $\begin{array}{l}\text { Funding decisions, } \\
\text { upscale results to other } \\
\text { countries or regions, gain } \\
\text { further funding sources, } \\
\text { evaluation planning }\end{array}$ & $\begin{array}{l}\text { Normal periodic } \\
\text { reporting } \\
\text { timeframe; } \\
\text { project end }\end{array}$ & Project reports, & International \\
\hline
\end{tabular}


Table 4. Cont.

\begin{tabular}{|c|c|c|c|c|c|}
\hline $\begin{array}{l}\text { Who Needs } \\
\text { Monitoring Info? }\end{array}$ & $\begin{array}{c}\text { What Monitoring } \\
\text { Information Do They Need? }\end{array}$ & Why Do They Need It? & $\begin{array}{l}\text { When Do They } \\
\text { Need It? }\end{array}$ & $\begin{array}{l}\text { In What Form Do } \\
\text { They Need It? }\end{array}$ & $\begin{array}{c}\text { Where Do They } \\
\text { Need It? }\end{array}$ \\
\hline $\begin{array}{l}\text { Science } \\
\text { community }\end{array}$ & $\begin{array}{l}\text { Geospatial data on ecosystem } \\
\text { trends, species biodiversity, } \\
\text { economic impacts, survival } \\
\text { rate of enriched forests, } \\
\text { community uptake of EbA. }\end{array}$ & $\begin{array}{l}\text { Establish regional trends, } \\
\text { improve decision support } \\
\text { platforms for integrating } \\
\text { ecosystem and social data }\end{array}$ & Continuing basis & $\begin{array}{l}\text { Raw and aggregated } \\
\text { data; geospatial files }\end{array}$ & $\begin{array}{l}\text { Globally and } \\
\text { regionally }\end{array}$ \\
\hline
\end{tabular}

Among the barriers that the GCF project is addressing is that GoTG and private sector entities reliant on ecosystem services have insufficient knowledge and technical capacity to promote natural resource-based businesses. The project addressed this gap by including policy support, institutional strengthening and knowledge generation. The aim is to increase the quality and availability of information to inform policymakers, researchers, investors and the general public on the relative effectiveness and commercial viability of large-scale EbA [31]. To achieve this aim, the EbA platform serves as a one-stop shop for obtaining details about the KPIs, baseline data on EbA interventions within local communities, case studies of successful natural resource-based businesses, lessons learned on implementation arrangements, return on investment, and best practices.

Specific functions of the EbA platform include:

- $\quad$ Supporting day-to-day project management by collecting and aggregating feedback from local communities on their social and economic development which in turn serves as a basis for dialogue with them.

- Building project data and high level KPIs required for donor reporting [8]. Similarly, KPIs can be used to assess effectiveness of project leadership while allowing for adaptive management of project implementation.

- Providing a geo-spatial platform (GIS) that serves as a basis for capturing, processing, storing and visualizing project data.

- Establishing a time series of vegetation cover change based on available satellite imagery for establishing regional trends.

- Building national and local capacity on how to promote communication and awareness of EbA potential to project stakeholders through management training.

\subsection{Baseline Survey for EbA Indicator Selection}

The GCF project team visited Gambian institutions to learn how they manage and share data and information. The team assessed quality, relevance, accuracy and metadata needed for project management and their capacity to host and manage new data systems.

The survey found that, given its unique history and size, The Gambia is reasonably well covered with EbA core data sets at the national level, but lacks datasets at local scales to support project management. Some of the geographic databases were produced from agreements between The Gambia Ministry of Local Governments and Lands and the Japan International Cooperation Agency to jointly conduct aerial surveys in the year 2000. These 1:50,000 scale databases include district-level data (e.g., administrative boundaries, socioeconomic data and settlement names), transportation layers, buildings, small objects, and other structures, water resources, and land cover and topographic features. These data layers were input to the preliminary project planning.

However, the survey identified several gaps in the available layers. The lowest level administrative boundary data available was the district level, thus missing the village level administrative and community forest boundaries and associated data needed for establishing the EbA project baseline. Available settlement, village, and community-level data were in point form rather than in polygon formats. The implication was that villagelevel maps would be derived from a combination of remote-sensing data and district-level point data and not from pre-existing polygon files. 


\subsection{Collection of Field Data}

Field data were collected to build the indicators and the platform was used for aggregation and analysis. For example, the entity "beneficiaries" had the following fields for each entry:

- $\quad$ Source of benefit

- $\quad$ Specific benefit

- Date of benefit generation

- Quantity

- Cash equivalent in local currency

- Destination (marketed or consumed)

- No. of female-headed households benefiting

- No. of male-headed households benefiting

- Location

- Any further description

The constituent metadata for each KPI were defined so that the data could be aggregated by type, by village, district, or higher levels, while accruing over different time periods.

\subsection{EbA Monitoring Platform Design and Development}

The workflow for the EbA platform development is depicted in Figure 2. The platform was developed in parallel with the indicator selection and refinement as new information concerning indicators and their attributes became available.

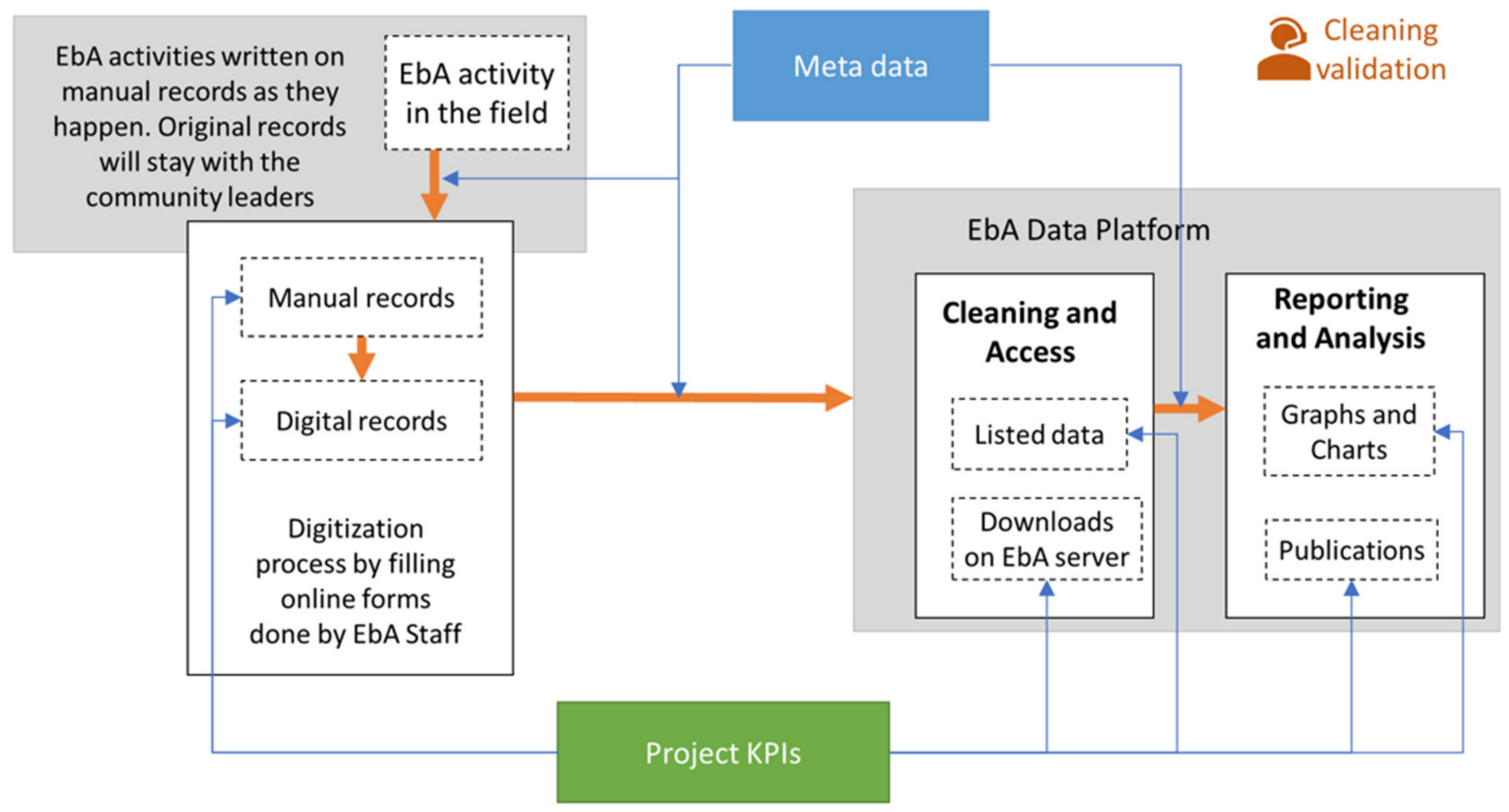

Figure 2. Workflow for EbA monitoring platform.

The platform design is based on location data from the four project regions identified within The Gambia (Lower River, Central River South, Central River North and Upper River Regions), entities (community forests, community protected areas, multipurpose centres (MPCs), individual households), and indicators. The platform tracks and displays the achievement of project impacts and is adaptive to details that emerge from the user community. 
Based on the indicator development, a web-based, data submission tool was built. The platform team developed the web pages using PHP programming language with the data residing in a MYSQL database. The web-based tool can be accessed from anywhere with an internet-enabled computer. The last step was to build an interactive dashboard to analyze and visualize the data. The dashboard calculates KPI values from field data.

The platform was presented to EbA project stakeholders during a hands-on workshop. Participants were presented with an interactive dashboard to visualize the data entered during field work. Modules included principles of data and information, data acquisition, data analysis, visualization of results, reporting and data quality. Trainees calculated KPI values, further prioritized the most important indicators as number of hectares restored, income generated (USD), and number of households benefitting from the project. One of the immediate impacts from the working sessions was the participants' growing awareness of the critical importance of village and community level data, leading to better ownership of data quality management.

The EbA monitoring platform was then directly linked to Geoportal so that results could be displayed spatially. The Geoportal is a suite of software products designed by the ICRAF GeoScience team to manage and disseminate geospatial data. In order to ensure sustainability after the completion of a project, the team developed a system based on Free and Open-Source Software for Geospatial (FOSS4G), with GeoNode (www.geonode. org (accessed on 1 October 2021)) as the software suite. To further strengthen the local ownership and sustainability, the EbA monitoring platform was linked to the web portal of the Ministry of Environment, Climate Change and Natural Resources. FOSS4G eliminates the need of expensive licenses to be renewed on an annual basis. The Gambia Geoportal modules include:

- User account module covers user registration, user types, account management, groups and access privileges.

- $\quad$ Layer module provides uploaded layers, a section to add new layers, metadata and style editing functionality and sharing functionality.

- Maps module allows users to view a list of previously created maps, create new maps, edit maps with new styling functionality.

- $\quad$ Search module allows users to search data based on access privileges.

- Administrator module explains additional privileges of a superuser. The administrator module also covers managing the GIS Server (GeoServer).

\subsection{EbA Platform Functionality}

The effective monitoring of EbA derives from accurate field data, so the platform is remotely accessible to the field team for data entry. Table 5 below summarizes the fields for data entry for each sub-indicator with respect to KPI \#1 relating to numbers of project beneficiaries. The data fields are similar to the other 25 KPIs. These fields captured the key descriptors: time, place, intervention, quantity, beneficiaries, and textual description.

Data for each of the sub-indicators were then aggregated to build into each of the KPIs. Figure 3 depicts the process by which data were aggregated in order to inform project managers of status and impact. Aggregation can be by area (village, district, region, or project wide) or theme (tree mortality, gender impact or both) to compute KPIs. 
Table 5. Detailed data fields for the sub-indicators aligned with the key performance indicators (here presented only for KPI 1 for illustration purposes only).

Key Performance Indicator 1. Number of Females and Males Benefiting

Sub-Indicators

Number of households benefiting from the project

Gender representation in the management committees
Detailed Data Fields for Sub-Indicators

General information

Date (year)

Village

Entity Community Forest (CF)/Community Protected Area

(CPA)/Multi-Purpose Centres (MPC)/Agric. Area)

Type of activity (List to be provided)

Type of benefit (No of household Female Headed (FH) and No of household Male Headed (MH))

Description

Entity details:

Name

Village $>$ district $>$ region

Type (CF/CPA/MPC/Agric. Area)

Area (hectares)

Date of establishment

Link to Map

Village

Select (Entity (1))

Date appointed

Name Date of birth

Status

Gender

Description

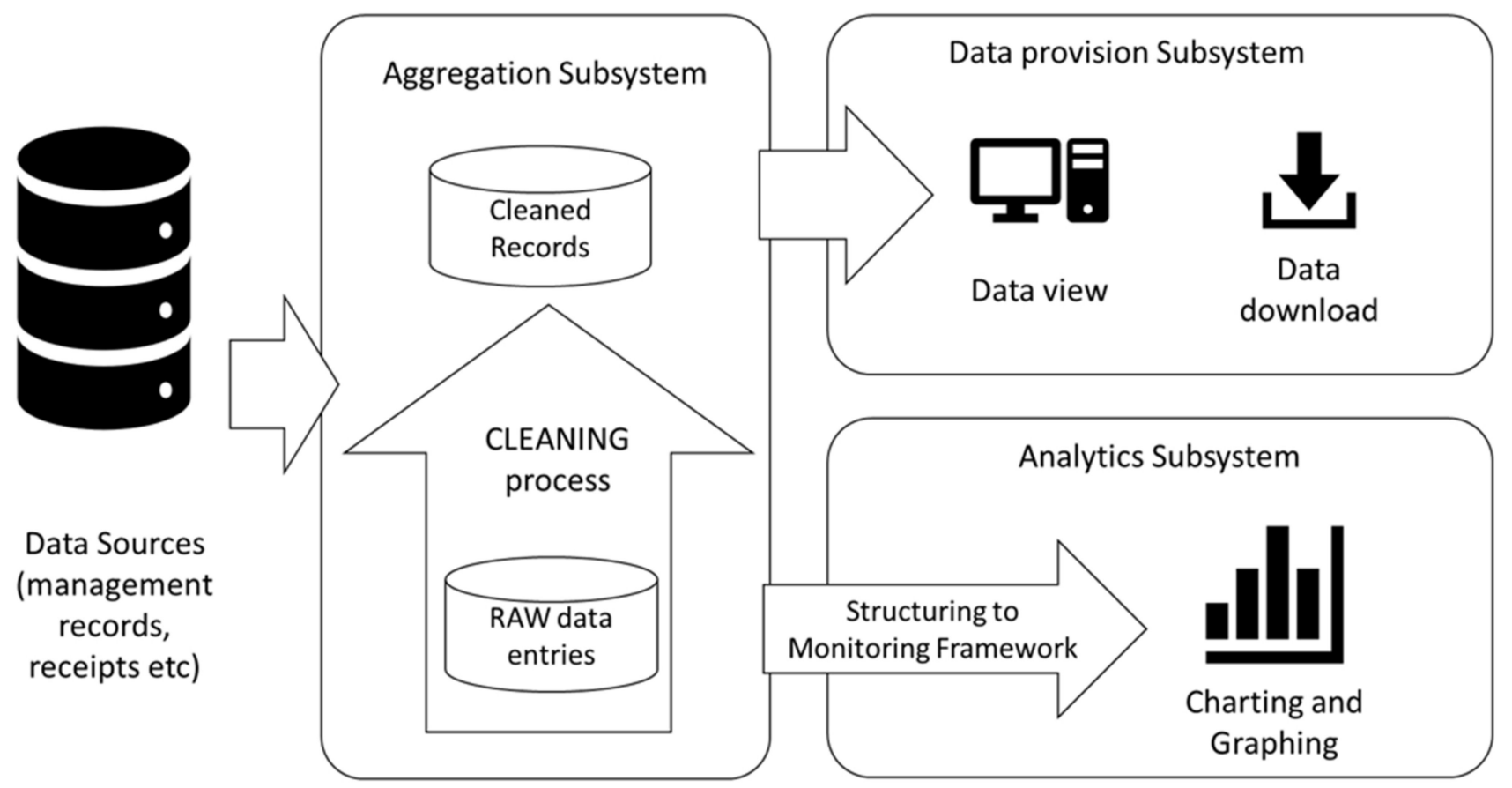

Figure 3. Data aggregation and KPI computation.

Data can then be aggregated, for example, to generate numbers of women participating in income-generating activities by village and compared with the same statistic for a different location. Another example is a comparative analysis of tree mortality by district to investigate possible causes. The results inform project managers how to better under- 
stand challenges to gender impact or tree health and then adapt management planning, if necessary.

Conditions for access include two levels, one for the general public and a higher security level requiring registration for data entry, managers, etc.

The institutions that execute $\mathrm{EbA}$ monitoring provide the framework's foundation, as their roles include not only data entry and indicator production, but also operating feedback loops to allow for adaptive management. Table 4 identifies these institutions and their information requirements. Information provided on a demand-driven basis is the key to grow the skills and capacity to back EbA implementation. As capacity grows, barriers to EbA implementation are alleviated as project stakeholders will have the confidence to make informed decisions. Moreover, sharing information across a network of institutions provides insights across sectors.

\section{Results: A Process for Indicator Selection, the EbA Framework with Its Platform, and Initial Applications}

The results comprise 3 elements: (i) a generic, user-friendly, 5 step process for selecting $\mathrm{EbA}$ indicators, (ii) a robust framework for EbA monitoring based on these indicators, and (iii) initial applications.

\subsection{The Five-Step Process for Selecting EbA Indicators}

The first step in indicator selection comprised a background review of three types of tool/document, including:

- a few, general documents on how ecosystem resilience is linked to climate change adaptation for background/context, such as those produced by the Intergovernmental Panel on Climate Change (IPCC), Intergovernmental Platform on Biodiversity and Ecosystem Services (IPBES), etc.

- general manuals, short courses, etc. for project management (results-based management, logframes, theory of change, adaptive management, etc.), and

- $\quad$ specific tools depending on the nature of the project such IT platforms to incorporate project data and information, including spatially explicit data, to support project planning, management, execution, monitoring, reporting and evaluation. These tools may integrate biophysical data with socio-economic data at a local project scale to understand win-wins, tradeoffs and impacts.

The second step consists of an expert review of indicators used for reporting to GCF or other donors to confirm applicability, refine indicators for reporting purposes, and explore potential adaptation for community-level use. The second step may include a review of EbA indicators from different contexts (urban, water, energy, biodiversity, etc.) and geographies (national, regional, continental) versus the local context. The initial assessment of indicators should include cost-effectiveness. Results from the second step feed into the initial platform design.

The third step is the in-country testing of the resulting indicator menu and includes visits to project sites, and consultations with Government, business and community leaders and members. Table 4 captures their data and information needs. Indicator refinement includes the development of second-level indicators that allow for targeted adaptation monitoring based on community priorities while aggregating to high level indicators. The platform design is similarly refined based on inclusion of second-level indicators. The assessment of cost effectiveness is continued.

The fourth step includes refinement and confirmation of indicators in a workshop environment. Such a broad consultation favors cross sector analysis and civil society inclusion.

The fifth step for selecting EbA indicators comprises data collection and analysis during project execution and applies principles of adaptive management as needed. Results from indicator use are also shared with the science community.

The final indicator set for the EbA Gambia project monitoring included sub-indicators that were easy to measure at relevant scale and could be aggregated for monitoring 
purposes. The final set was developed after the realization that the EbA interventions were broader than what is described in the initial set of KPIs selected during project design. Table 6 presents the final set of KPIs and sub-indicators used for monitoring EbA adaptation.

Table 6. Final set of KPIs and sub-indicators agreed for the EbA Gambia project, with designation as output or outcome indicators.

Key Performance Indicator

Number of females and males benefiting

Total area of degraded ecosystems restored by EbA interventions.

\section{Sub-Indicators}

Number of households benefiting from the project (output)

Gender representation in the management committee (outcome)

Area planted with trees (ha) (output)

Area of agricultural land area developed (ha) (output)

Area of forest restored (ha) (output)

Number of trees planted in different planting arrangements (output)

Number of incidents of illegal extraction (outcome)

Number of uncontrolled fire incidences in CF/CPA (outcome)

Area of fire belt established (ha) (output)

Frequency of patrolling CFs/CPAs per month (outcome)

Number of awareness creation events on EbA (output)

No. of technical staff trained (Including extension staff) (output) Income per household (USD) (output)

Livelihood improvement for Rural Gambian households

Number of direct jobs created through natural resource-based enterprises (output)

Number of NR-based enterprises in CFs, CPAs and Multipurpose Committees (MPCs (output)

Number of enterprises based on a climate-resilient natural resource base.

\begin{tabular}{c}
\hline Investments in NR-based businesses (USD) (output) \\
\hline Investments in MPCs (USD) (output) \\
\hline Investments in nursery developments (USD) (output) \\
\hline Revenue from NR-based businesses (USD) (outcome)
\end{tabular}

Number of communities trained on NR-based enterprises (output)

Number of policies, strategies and plans integrating EbA (output)

EbA integration score of policies, strategies, plans and processes

Number of national and regional level policy dialogues held on EbA (output)

Number of local management plans integrating EbA protocols developed

Number of assessments and strategic policy recommendations developed to support integration of large-scale EbA into sectoral policies and plans.
Number of management plans updated to include EbA (output)

Number of EbA related policy recommendations developed (outcome)

Number of assessments conducted on the different policies, strategies and plans related to $\mathrm{EbA}$. (output)

Contribution to National Forest Fund to facilitate effective forest management in the country

Amount of tax and license fees collected from NR-businesses (USD) (outcome)

The development of the EbA monitoring framework yields immediate benefits for the rural community. In particular, the initial set of performance indicators provided by the GCF mostly focused on values set for reporting to the donor. Therefore, the production of community-driven performance indicators directs the project investments toward results that provide benefits to the end users and ultimately enhance The Gambia's efforts to adapt 
to climate change based on the inherent capacity of its ecosystem resources and the rural population that depends on them. A less tangible but nevertheless important benefit is that the EbA project managers in The Gambia were exposed to processes for monitoring impacts that orient them increasingly toward rural community needs. The benefit can be realized in other efforts during their professional careers.

\subsection{The EbA Monitoring Framework: Design and Functionality}

Figure 4 presents the conceptual framework design, "The System", with its component functions. The System is designed from an organizational perspective to provide a robust architecture for other EbA initiatives globally. The Use the System activity enables internal EbA Gambia project users to perform tasks on handling project-related data, information, and projects as well as reporting, while providing the necessary description of requirements to the Manage and Oversee the System activity for completing their tasks. These user requirements govern the System. The resulting data are analyzed to help in developing and enforcing policies, guidance, direction, and standards to manage the protection, control, and implementation of the resources needed to deliver the EbA Gambia Platform. The Protect and Secure the System activity takes security parameters from the Manage and Oversee the System activity for the Platform resources to minimize their vulnerability to both exploitation and attack, and to prevent unauthorized use. Both the Protect and Secure the System activity and the Control and Operate the System activity monitor the System for vulnerabilities and provide appropriate responses to detected incidents. The Control and Operate the System activity takes policy, guidance, and direction from the Manage and Oversee the System and works to ensure the delivery of the EbA Gambia platform. The Provide System Platform activity supplies the elements and components that underpin the tasks to catalog EbA resources, collate EbA data, and report on project status and progress.

The above Methods section describes the data and information that are collected, flow through the platform, and used to produce statistics and support decision making.

The Gambia EbA data and information platform can be accessed at http:/ / ebaproject. worldagroforestry.org/ (accessed on 1 October 2021).

Framework Limitations

Although the process for developing indicators is re-useable and the framework can be adapted to different contexts, the platform developed for the GCF Gambia project would need to be adjusted depending on context and user needs. In time, as knowledge of new management needs is refined, the platform would need to be further adapted.

Finally, although user training is not a limitation, a training programme is a required component in framework development.

\subsection{Examples of Initial EbA Monitoring Applications for EbA Planning}

Figure 5 depicts the results of preliminary spatial analysis to show preferred areas for EbA activities such as beekeeping, forest species enrichment planting, and forest products enterprises adjacent to the community of Gaindeh Njie.

The above results were assessed by community leaders and the EbA project team in order to prioritize the locations and types of EbA intervention. 

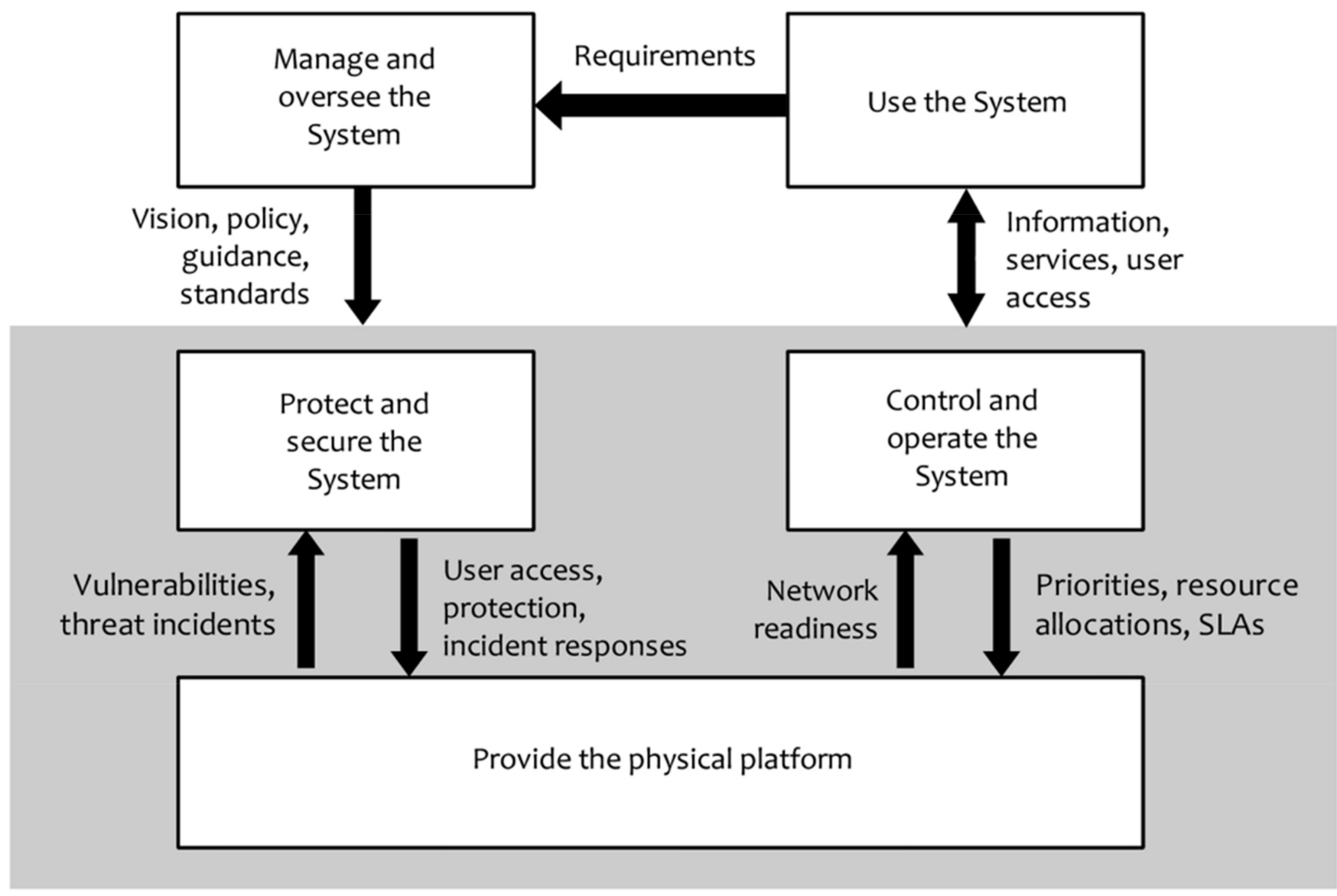

Figure 4. EbA Gambia conceptual framework design (SLAs-service level agreements). 


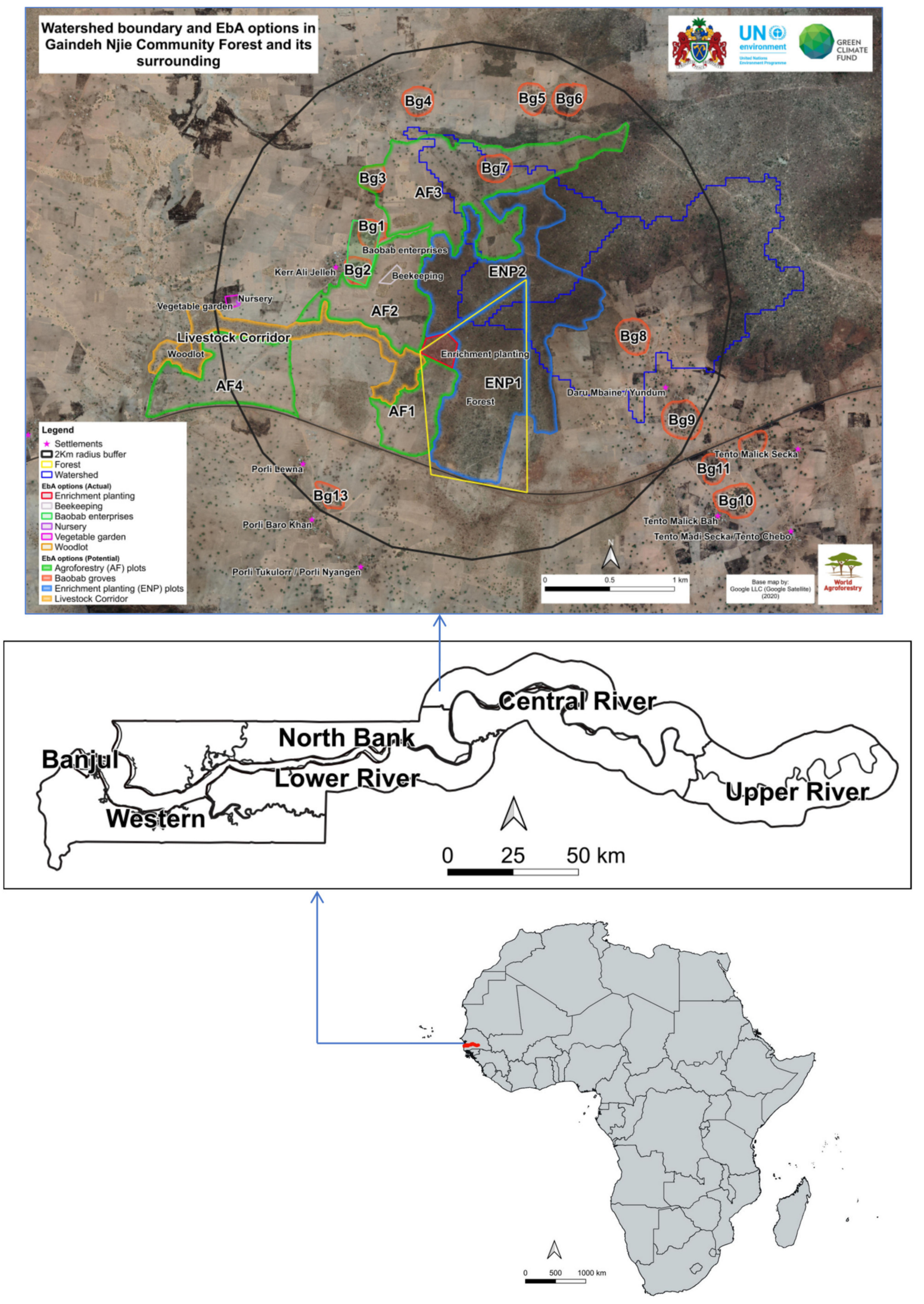

Figure 5. Village level planning map for Gaindeh Njie. 


\section{Discussion and Conclusions}

The research presented here respects the requisite five EbA principles mentioned in the introduction and proposes a monitoring framework which includes indicators that address each of them. The findings support the position that, although a universal framework is not applicable to all EbA initiatives, the framework and process from EbA Gambia reflects a strong agreement from beneficiaries and can be used for EbA projects with similar objectives.

The results presented here build on previous research (for example, Sanneh et al. [32]) to prioritize approaches to CC adaptation through the implementation of The Gambia's NAPA.

The framework contributes to our global understanding of how best to use ecosystem resources for adapting to climate change and offers a framework that can be adapted to other regions. It complements the set of tools described in Table 2 by offering a robust framework within which such tools can be applied.

The benefit of the GCF/Gambia EbA monitoring is to allow users to analyze trends in socio-economic growth within the target communities (changes in income level, diversity of livelihoods increased, increase in numbers and diversity of community groups working in $\mathrm{EbA}$ ) along with changes in ecosystem status (\% tree cover, tree species diversity) to adjust project management and inform policy as needed. The platform can be adapted, with modifications, to other community-based, EbA projects.

The robust framework allows for donor reporting while tracking impacts most relevant to local community needs.

An unanticipated impact was the project managers and implementers' increased awareness of the critical importance of community-level data, leading to better ownership of data quality management. Within the GCF/Gambia project team, users appreciated the importance of accommodating changes in KPIs and associated attributes during the validation exercise. Only when data are collected in the field is it possible to understand the issues surrounding data aggregation, relevance and possible weaknesses with the KPIs.

The main gaps are those related to the utility of the platform beyond reporting on KPIs for which project activities were initially focused. Future research needs will focus on making the platform more robust to explore and support new management needs.

Such adaptation monitoring frameworks and the information they generate will always be needed for effective EbA projects. Nevertheless, the authors emphasize the importance of on-the-ground experience particularly when interpreting integrated biophysical with socio-economic data and information.

Further research will be needed to understand the extent to which the changes in The Gambia compare to environmental changes across the Sahel and Sudano-Sahel in West Africa. For example, project results will be compared with regional vegetation greenness indices over a 5-10 year period to show impacts and trends. This task goes beyond the remit of the current GCF/The Gambia project, however it is globally and regionally relevant because it demonstrates how to adapt to the worst of climate change impacts.

Author Contributions: Conceptualization, L.A.D., P.G. and P.A.M.; methodology, L.A.D., P.G. and P.A.M.; software, S.M., M.A.; validation., A.B., M.S.J.; formal analysis, L.A.D., P.G.; writing—original draft preparation, P.G., L.A.D.; writing—review and editing, L.A.D., P.G., A.B., M.S.J.; visualization, S.M., M.A.; supervision, L.A.D.; funding acquisition, L.A.D., P.A.M., P.G. and L.A.D. contributed equally to the manuscript. All authors have read and agreed to the published version of the manuscript.

Funding: This research is a product from the project "Large-scale Ecosystem-based Adaptation in The Gambia: developing a climate-resilient, natural resource-based economy" funded by the Green Climate Fund (FP 011) and executed by the Government of The Gambia and implemented by the United Nations Environment Programme (UNEP).The opinions and the views expressed in this document are of the authors, and not of the donors or other institutions involved in the project.

Data Availability Statement: Not applicable. 
Acknowledgments: We are very grateful for the support on the maps by Jane Wanjara and Anulisa Claire. We are also very grateful for the technical support of the EbA project field teams in commenting on the monitoring tool.

Conflicts of Interest: The authors declare no conflict of interest. The funders had no role in the design of the study; in the collection, analyses, or interpretation of data; in the writing of the manuscript, or in the decision to publish the results.

$\begin{array}{ll}\text { Abbreviations } & \\ \text { CBD } & \text { UN Convention on Biodiversity } \\ \text { CCA } & \text { Climate Change Adaptation } \\ \text { CFs } & \text { Community Forests } \\ \text { CPAs } & \text { Community Protected Areas } \\ \text { EbA } & \text { Ecosystems based Adaptation } \\ \text { EC } & \text { European Commission } \\ \text { GCF } & \text { Green Climate Fund } \\ \text { FAO } & \text { UN Food and Agricultural Organization } \\ \text { GEF } & \text { Global Environment Facility } \\ \text { GIZ } & \text { Deutsche Gesellschaft für Internationale Zusammenarbeit } \\ \text { GoTG } & \text { Government of The Gambia } \\ \text { ICRAF } & \text { International Centre for Research in Agroforestry } \\ \text { IFAD } & \text { International Fund for Agricultural Development } \\ \text { IIED } & \text { International Institute for Environment and Development } \\ \text { IPBES } & \text { Intergovernmental Platform on Biodiversity and Ecosystem Services } \\ \text { IPCC } & \text { Intergovernmental Panel on Climate Change } \\ \text { IUCN } & \text { Interna-tional Union for the Conservation of Nature } \\ \text { KPIs } & \text { Key Performance Indicators } \\ \text { MECCNR } & \text { Ministry of Environment, Climate Change and Natural Resources } \\ \text { MPC } & \text { Multipurpose Committees } \\ \text { NBS } & \text { Nature Based Solutions } \\ \text { SLM } & \text { Sustainable Land Management } \\ \text { UNEP } & \text { UN Environment Programme } \\ \text { UNEP-WCMC } & \text { UNEP-World Conservation Monitoring Centre } \\ & \end{array}$

\section{References}

1. United Nations, Department of Economic and Social Affairs, Population Division. World Population Prospects 2019: Highlights; 2019 Revision Highlights, 2019 Revision; United Nations: New York, NY, USA, 2019; ISBN 978-92-1-148316-1.

2. Masson-Delmotte, V.; Intergovernmental Panel on Climate Change; WMO; United Nations Environment Programme. Climate Change and Land: An IPCC Special Report on Climate Change, Desertification, Land Degradation, Sustainable Land Management, Food Security, and Greenhouse Gas Fluxes in Terrestrial Ecosystems: Summary for Policymakers; Intergovernmental Panel on Climate Change: Geneva, Switzerland, 2019; ISBN 978-92-9169-154-8.

3. Stocker, T.; Qin, D. (Eds.) Climate Change 2013: The Physical Science Basis: Summary for Policymakers, a Report of Working Group I of the IPCC: Technical Summary, a Report Accepted by Working Group I of the IPCC but Not Approved in Detail: And Frequently Asked Questions: Part of the Working Group I Contribution to the Fifth Assessment Report of the Intergovernmental Panel on Climate Change; WMO: New York, NY, USA; Cambridge University Press: Cambridge, UK, 2013; ISBN 978-92-9169-138-8.

4. Riede, J.O.; Posada, R.; Fink, A.H.; Kaspar, F. What's on the 5th IPCC Report for West Africa? In Adaptation to Climate Change and Variability in Rural West Africa; Yaro, J.A., Hesselberg, J., Eds.; Springer International Publishing: Cham, Switzerland, 2016; pp. 7-23. ISBN 978-3-319-31497-6.

5. Ajayi, V.O.; Ilori, O.W. Projected Drought Events over West Africa Using RCA4 Regional Climate Model. Earth Syst. Environ. 2020, 4, 329-348. [CrossRef]

6. Platts, P.J.; Omeny, P.A.; Marchant, R. AFRICLIM: High-Resolution Climate Projections for Ecological Applications in Africa. Afr. J. Ecol. 2015, 53, 103-108. [CrossRef]

7. Mastrandrea, M.D.; Mach, K.J.; Plattner, G.-K.; Edenhofer, O.; Stocker, T.F.; Field, C.B.; Ebi, K.L.; Matschoss, P.R. The IPCC AR5 Guidance Note on Consistent Treatment of Uncertainties: A Common Approach across the Working Groups. Clim. Chang. 2011, 108, 675-691. [CrossRef]

8. Duguma, L.A.; Borona, P.; Minang, P.A.; Nzyoka, J.; Bah, A.; Gilruth, P.; Makui, P.; Carsan, S.; Kindt, R.; Foundjem, D.; et al. Diagnostic and a Baseline Study for Implementing Ecosystem-Based Adaptation in Rural Landscapes of The Gambia; World Agroforestry (ICRAF): Nairobi, Kenya, 2020; p. 145. 
9. James, R.; Washington, R.; Abiodun, B.; Kay, G.; Mutemi, J.; Pokam, W.; Hart, N.; Artan, G.; Senior, C. Evaluating Climate Models with an African Lens. Bull. Am. Meteorol. Soc. 2018, 99, 313-336. [CrossRef]

10. Secretariat of the Convention on Biological Diversity (CBD). Connecting Biodiversity and Climate Change Mitigation and Adaptation: Report of the Second Ad Hoc Technical Expert Group on Biodiversity and Climate Change; The Secretariat of the Convention on Biological Diversity: Montreal, QC, Canada, 2009; p. 126.

11. FEBA (Friends of Ecosystem-based Adaptation). Making Ecosystem-Based Adaptation Effective: A Framework for Defining Qualification Criteria and Quality Standards; FEBA Technical Paper Developed for UNFCCC-SBSTA 46; GIZ: Bonn, Germany; IIED: London, UK; IUCN: Gland, Switzerland, 2017.

12. Scarano, F.R. Ecosystem-Based Adaptation to Climate Change: Concept, Scalability and a Role for Conservation Science. Perspect. Ecol. Conserv. 2017, 15, 65-73. [CrossRef]

13. IUCN (International Union for Conservation of Nature). Ecosystem-Based Adaptation; IUCN: Gland, Switzerland, 2017.

14. Cohen-Shacham, E.; Walters, G.; Janzen, C.; Maginnis, S. (Eds.) Nature-Based Solutions to Address Global Societal Challenges; IUCN International Union for Conservation of Nature: Gland, Switzerland, 2016; ISBN 978-2-8317-1812-5.

15. Reid, H.; Hou Jones, X.; Porras, I.; Hicks, C.; Wicander, S.; Seddon, N.; Kapos, V.; Rizvi, A.R. Is Ecosystem-Based Adaptation Effective? Perceptions and Lessons Learned from 13 Project Sites; International Institute for Environment and Development: London, UK, 2019; p. 109.

16. The Green Climate Fund. Approved Projects. Available online: https:/ /www.greenclimate.fund/projects (accessed on 18 July 2021).

17. Christiansen, L.; Martinez, G.; Naswa, P.; UNEP DTU Partnership. Adaptation Metrics—Perspectives on Measuring, Aggregating and Comparing Adaptation Results; UNEP DTU Partnership: Copenhagen, Denmark, 2018; ISBN 978-87-93458-27-7.

18. Doubleday, A.; Errett, N.A.; Ebi, K.L.; Hess, J.J. Indicators to Guide and Monitor Climate Change Adaptation in the US Pacific Northwest. Am. J. Public Health 2020, 110, 180-188. [CrossRef] [PubMed]

19. Ebi, K.; Boyer, C.; Bowen, K.; Frumkin, H.; Hess, J. Monitoring and Evaluation Indicators for Climate Change-Related Health Impacts, Risks, Adaptation, and Resilience. Int. J. Environ. Res. Public Health 2018, 15, 1943. [CrossRef] [PubMed]

20. Klostermann, J.; van de Sandt, K.; Harley, M.; Hildén, M.; Leiter, T.; van Minnen, J.; Pieterse, N.; van Bree, L. Towards a Framework to Assess, Compare and Develop Monitoring and Evaluation of Climate Change Adaptation in Europe. Mitig. Adapt. Strateg. Glob. Chang. 2018, 23, 187-209. [CrossRef] [PubMed]

21. Zischg, A.; Schober, S.; Sereinig, N.; Rauter, M.; Seymann, C.; Goldschmidt, F.; Bäk, R.; Schleicher, E. Monitoring the Temporal Development of Natural Hazard Risks as a Basis Indicator for Climate Change Adaptation. Nat. Hazards 2013, 67, 1045-1058. [CrossRef]

22. Feldmeyer, D.; Wilden, D.; Kind, C.; Kaiser, T.; Goldschmidt, R.; Diller, C.; Birkmann, J. Indicators for Monitoring Urban Climate Change Resilience and Adaptation. Sustainability 2019, 11, 2931. [CrossRef]

23. Larson, S.; Kirono, D.G.C.; Tjandraatmadja, G.; Barkey, R. Monitoring and Evaluation Approaches in Water Resources Project Design: Experiences from an Urban Water System Climate Change Adaptation Project in Indonesia. Water Policy 2016, 18, 708-726. [CrossRef]

24. Pineda, A.A.L.; Vélez Rojas (Oscar), O.A.; Jonathan, M.P.; Sujitha, S.B. Evaluation of Climate Change Adaptation in the Energy Generation Sector in Colombia via a Composite Index-A Monitoring Tool for Government Policies and Actions. J. Environ. Manag. 2019, 250, 109453. [CrossRef] [PubMed]

25. European Commission. Directorate General for Research and Innovation. In Evaluating the Impact of Nature-Based Solutions: A Handbook for Practitioners; Publications Office of the European Union: Luxembourg, 2021.

26. Conroy, M.J.; Runge, M.C.; Nichols, J.D.; Stodola, K.W.; Cooper, R.J. Conservation in the Face of Climate Change: The Roles of Alternative Models, Monitoring, and Adaptation in Confronting and Reducing Uncertainty. Biol. Conserv. 2011, 144, 1204-1213. [CrossRef]

27. Ricci, P.F.; Sheng, H. Benefits and Limitations of the Precautionary Principle. In Reference Module in Earth Systems and Environmental Sciences; Elsevier: Amsterdam, The Netherlands, 2013; p. B9780124095489020000, ISBN 978-0-12-409548-9.

28. African Network on Participatory Approaches; Koninklijk Instituut voor de Tropen; World Bank. Village Participation in Rural Development: Manual; The World Bank: Washington, DC, USA, 2000; ISBN 978-90-6832-136-4.

29. International Fund for Agricultural Development. Cross-Cutting Capacity Building, Knowledge Services and Coordination Project for the Food Security Integrated Approach Pilot Program - GEF Project 9140; International Fund for Agricultural Development: Rome, Italy, 2016.

30. Ziadat, F.; Bunning, S.; De Pauw, E.; Food and Agriculture Organization of the United Nations. Land Resource Planning for Sustainable Land Management: Current and Emerging Needs in Land Resource Planning for Food Security, Sustainable Livelihoods, Integrated Landscape Management and Restoration: A Review of Needs at Various Scales for Tools and Processes That Help Countries and Stakeholders Meet Emerging Challenges, Address Increasing Degradation of and Competition for Resources, Support the Sustanable Use and Restoration of Land and Water Resources, and Ensure Resilient Ecossystems; Food and Agriculture Organization of the United Nations: Rome, Italy, 2017; ISBN 978-92-5-109896-7.

31. United Nations Environment Programme. Green Climate Fund Funding Proposal 011: Large-Scale Ecosystem-Based Adaptation in the Gambia River Basin: Developing a Climate Resilient, Natural Resource-Based Economy; Gambia United Nations Environment Programme (UNEP): Nairobi, Kenya, 2016. 
32. Sanneh, E.S.; Hu, A.H.; Hsu, C.-W.; Njie, M. Prioritization of Climate Change Adaptation Approaches in the Gambia. Mitig. Adapt. Strateg. Glob. Chang. 2014, 19, 1163-1178. [CrossRef]

33. Field, C.B.; Barros, V.R.; Dokken, D.J.; Mach, K.J.; Mastrandrea, M.D. Fifth Assessment Report (AR5): Climate Change 2013/2014: Climate Change 2014: Impacts, Adaptation, and Vulnerability; Part B; IPCC Working Group: New York, NY, USA; Cambridge University Press: New York, NY, USA, 2014; Volume 2, ISBN 978-1-107-41538-6. 